\title{
Research of Column microbial desulfurization of high sulfur coal
}

\author{
B. WU, H. SHANG, J.K. WEN \\ National Engineering Laboratory of Biohydrometallurgy, General Research Institute for Nonferrous Metals, \\ Beijing, China
}

\begin{abstract}
A study was made to desulphurize the coal from WuHai of Nei Meng Gu province in China, characterized by high content of sulphur (2.85\%) and high content of organic sulphur $(0.49 \%)$ by using the mesophilic bac-terias isolated from WuHai coal. In the present investigation, while using these natural microbial strains, the optimum results were obtained under conditions of desulphurization was carried out when coal particle size of $-6 \mathrm{~mm}$ and column height 1.5 meters after continuous treatment for 6 days. Maximum total sulphur concentration of the desulphurized coal was $0.70 \%$, a desulphurize rate, as high as, $70-80 \%$ of inorganic and 40-50\% organic sulphur demonstrated the efficiency of using the mesophilic bacteria for desulphurization, the result showed that the ash content was reduced and the calorific value was increased due to gangue minerals dis-solved in acidic mediums.
\end{abstract}

KEYWORD: Organic sulphur; Desulfurization; Coal

\section{INTRODUCTION}

Coal is one of the most important fossil fuels sources for energy supply, China is the largest producer of coal in the world, the China's coal production has reached 1.36 billion tons in 2015, over eighty percent of which is used for power generation. With the deep mining, sulfur content in coal gradually increased to $2 \mathrm{wt} \%$, releasing of sulphur dioxide into the air and our environment has constantly been polluted by coal combustion, which has received extreme attention throughout the world. Reducing of these gases are essential to our environmental protection, China's government has formulated the law about prevention and treatment of air pollution, which regulated the coal prohibit to use when sulfur content higher than $0.8 \mathrm{wt} \%$. Microbial desulfurization of coal is one option for emissions control of sulfur when burning coal (G. Olsson et al., 1994), sulphur occurs in coal in both organic and inorganic forms. The major part of the inorganic sulfur in coal consists of pyrite, $80-90 \%$ of the inorganic sulphur can be removed by using mesophilic and acidophilic bacterium Thiobacillus ferrooxidans. Compared with the removal of inorganic sulfur element, the eliminate of organic sulfur is very difficult(C Acharya et al., 2001). The organic sulfur is a component of organic matter in coal and embedded in the coal matrix lattice, so remove organic sulfur from coal need to destroy the C-S bonds. There have been several researches on organic sulphur removal from coal with various bacteria [2-4], including the fungi, which has ability to metabolize a wide range of hydrocarbons through the react of cytochrome p-450 and enzymes. Celin et al.,( 2005) Newly isolated strain Aspergillus sp. from Assam coal could remove 78\% of total sulphur under conditions of coal grinding fineness of $-74 \mu \mathrm{m}$ and $2 \%$ (w/v) pulp density for the process duration of 10 days.

Lot of North China coals contain sulphur higher than $2.0 \mathrm{wt} \%$, the sulphur is found mainly occurs in organic sulfur, which is very difficult to be eliminated by floatation and other chemical methods. The present investigation focus on study the degree of column eliminate of sulphur from high sulphur coal using native efficient microorganisms isolated from coal acid mine drainage.

\section{MATERIALS AND METHODS}

\subsection{Coals}

The coal samples in this study were obtained from Nei Meng Gu province of China. Its elemental composition, proximate analyses and metal analyses are listed in Table 1.

\subsection{Organisms}

The mixed culture of acidophilic bacteria used in this study was isolated from coal acid mine drainage, 
the medium used was "Leathen's" medium $\left(\mathrm{K}_{2} \mathrm{HPO}_{4}\right.$ $0.05 \mathrm{~g} / \mathrm{l},\left(\mathrm{NH}_{4}\right)_{2} \mathrm{SO}_{4} 0.15 \mathrm{~g} / \mathrm{l}, \mathrm{MgSO}_{4} * 7 \mathrm{H}_{2} \mathrm{O} 0.05 \mathrm{~g} / \mathrm{l}$, $\left.\mathrm{Ca}\left(\mathrm{NO}_{3}\right)_{2} 0.01 \mathrm{~g} / \mathrm{l}, \mathrm{KC} 10.05 \mathrm{~g} / \mathrm{l}\right)$, in the experiments with coal, yeast extract of $1 \mathrm{~g} / \mathrm{L}$ was added to the "Leathen's" medium.

Table 1. Chemical composition of coal sample.

\begin{tabular}{lc}
\hline Mineral & Content(wt\%) \\
\hline Total sulfur & 2.85 \\
Pyritic sulfur & 2.36 \\
Organic sulfur & 0.49 \\
Ash & 2.83 \\
Calorific value & $5780 \mathrm{Kcal}$ \\
\hline
\end{tabular}

\subsection{Column operation}

Four columns (125 mm internal diameter,1.5 meters height ) were established, the temperature controlled at $35-45^{\circ} \mathrm{C}$. Each column contained $4-5 \mathrm{~kg}$ of ore, top size controlled to $-6 \mathrm{~mm}$ (1\#colunm), $-8 \mathrm{~mm}$ (2\#colunm) and $-10 \mathrm{~mm}$ (3\#colunm) respectively. The columns were irrigated(flow rate $10 \mathrm{Lm}^{-2} \mathrm{~h}^{-}$ ${ }^{1}$ )with acidified solutions at the set points $\mathrm{pH} 1.8$ until the $\mathrm{pH}$ values for the column leachate matched the selected set points.

Each column was then inoculated with mixed bacterial cultures suited to the selected temperatures and containing sulfur oxidising species, no further acid was added once the biooxidation of the sulfur generated acid and the $\mathrm{pH}$ values of the leachate dropped below their respective set points. A fourth column (4\#column,top size $-8 \mathrm{~mm}$ ) discharge solutions neutralized with lime periodically in order to get rid of sulfate and ferric ions. During column biooxidation, the solution $\mathrm{pH}$ and redox potential were monitored periodically and solution samples withdrawn for element analysis.

\section{RESULTS AND DISCUSSION}

\subsection{Sulfur elimination}

With the exception of the $4 \#$ columns, the column discharge solutions reflected the $\mathrm{pH}$ set points rapidly (Fig.1). When four columns be inoculated with the same mixed culture, ORP values and mixed cells rose rapidly (Fig.2 and Fig.3) indicating strong microbial activity in those columns.

In the $4 \#$ column (discharge solutions neutralized with lime periodically), the $\mathrm{pH}$ fluctuated between 1.8 and 2.0 for the acid generated by bacteria consumed with lime periodically. Colonisation by sulfur-oxidising microorganisms was indicated by decrease in $\mathrm{pH}$ from about day 25. Colonisation by iron-oxidising microorganisms was indicated by the rise in ORP from about day 10. The higher ORP in that column reflected increased ferric ion concentrations that caused the oxidation of pyrite but the gen- eration of sulfate would be absorbed on the surface of coal, which would inhibit oxidation of sulfur noticeably. Sulfate from the oxidation of pyrite and organic sulfur in the coal was generated in all columns and was attributed to the ferric iron hydrolysis and jarosite precipitation during passage through the coal bed. Acid was generated from the partial biooxidation of pyrite (60-80\% oxidized) and organic sulfur (30-50\% oxidized). Some of that acid may be consumed by the partial dissolution of carbonate gangue minerals.

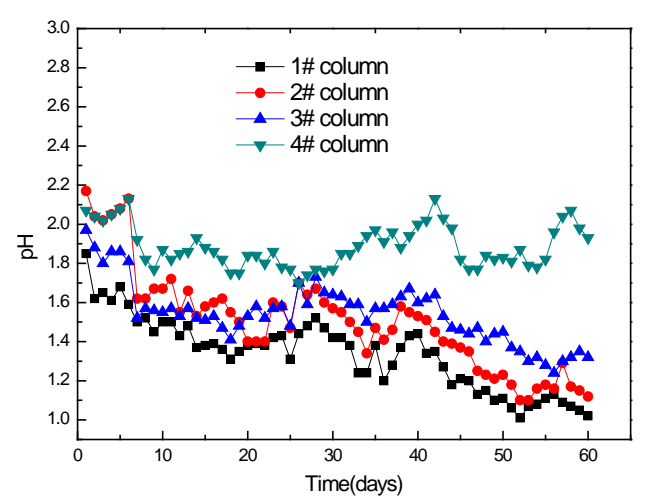

Fig.1 Discharge solution $\mathrm{pH}$ as a function of time

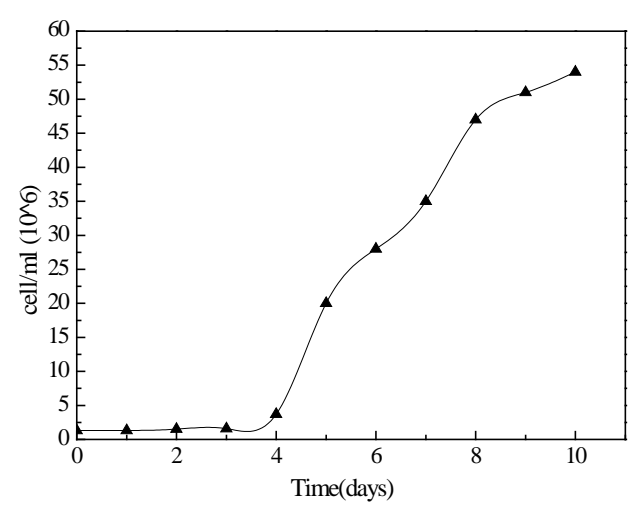

Fig.2 Count cells of mixed culture as a function of time

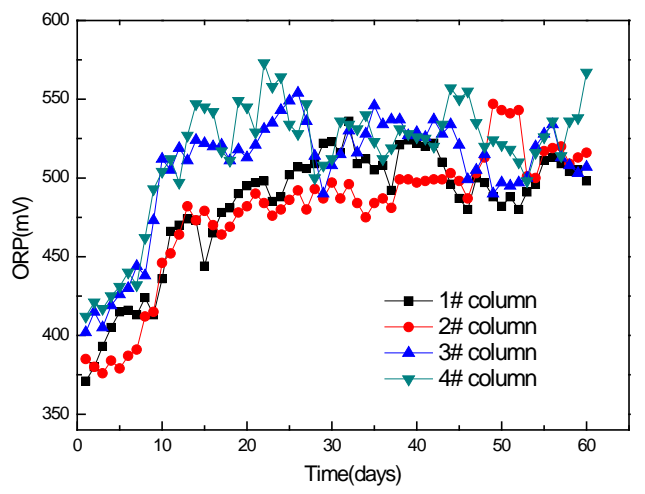

Fig.3 Discharge solution ORP as a function of time 


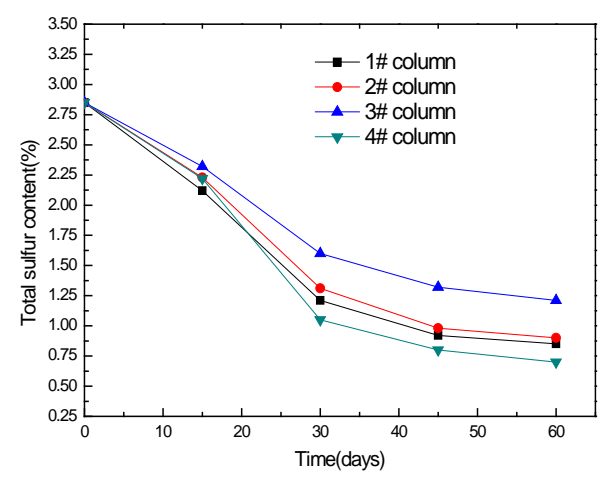

Fig.4 Sulfur content in four columns after microbial oxidation

The sulfur oxidation kinetics correlated closely with coal size and sulfate ion concentration in inoculated columns, increased size had large effect on elimination of sulfur, degree of remove of total sulphur was increased at the smaller coal size(Fig.4 and Table 2). The result show that a more effective remove of total sulphur with the extension in oxidation time from 10-45days, the growth rate of desulphurisation very slow above 45 days. Further prolongation of the oxidation time exceed 45 days would lead to unnecessary accumulating of sulfate and there was no more increase in the rate of sulphur remove from coal. Therefore the experiments were ended beyond 60 days, the rate of total sulphur elimination was found to be $70.18 \%$ in smaller size $(-6 \mathrm{~mm})$ in contrast to the coarser case $(-10 \mathrm{~mm})$, which was $57.54 \%$.

Table 2. Sulfur analyses of coal after desulphurisation

\begin{tabular}{|c|c|c|c|c|c|}
\hline \multirow{2}{*}{\multicolumn{2}{|c|}{ Analyses (wt\%) }} & \multicolumn{4}{|c|}{ Duration(days) } \\
\hline & & 15 & 30 & 45 & 60 \\
\hline \multirow{3}{*}{$1 \#$} & $\begin{array}{l}\text { Total } \\
\text { sulfur }\end{array}$ & 2.12 & 1.21 & 0.92 & 0.85 \\
\hline & $\begin{array}{l}\text { Pyritic } \\
\text { sulfur }\end{array}$ & 1.71 & 0.89 & 0.66 & 0.62 \\
\hline & $\begin{array}{c}\text { Organic } \\
\text { sulfur }\end{array}$ & 0.42 & 0.31 & 0.26 & 0.23 \\
\hline \multirow{3}{*}{ 2\# } & $\begin{array}{l}\text { Total } \\
\text { sulfur }\end{array}$ & 2.23 & 1.31 & 0.98 & 0.90 \\
\hline & $\begin{array}{l}\text { Pyritic } \\
\text { sulfur }\end{array}$ & 1.80 & 0.97 & 0.71 & 0.65 \\
\hline & $\begin{array}{c}\text { Organic } \\
\text { sulfur }\end{array}$ & 0.43 & 0.35 & 0.28 & 0.25 \\
\hline \multirow{3}{*}{ 3\# } & $\begin{array}{l}\text { Total } \\
\text { sulfur }\end{array}$ & 2.32 & 1.60 & 1.32 & 1.21 \\
\hline & $\begin{array}{l}\text { Pyritic } \\
\text { sulfur }\end{array}$ & 1.88 & 1.23 & 0.98 & 0.90 \\
\hline & $\begin{array}{c}\text { Organic } \\
\text { sulfur }\end{array}$ & 0.44 & 0.39 & 0.35 & 0.30 \\
\hline \multirow{3}{*}{ 4\# } & $\begin{array}{l}\text { Total } \\
\text { sulfur }\end{array}$ & 2.22 & 1.05 & 0.80 & 0.70 \\
\hline & $\begin{array}{l}\text { Pyritic } \\
\text { sulfur }\end{array}$ & 1.81 & 0.71 & 0.57 & 0.47 \\
\hline & $\begin{array}{c}\text { Organic } \\
\text { sulfur }\end{array}$ & 0.42 & 0.35 & 0.28 & 0.24 \\
\hline
\end{tabular}

Few sulfur content were decreased in the period 0-10 days during which acid was added periodically to supplement gangue mineral consumption, but fast elimination achieved for sulfur when the colonisation occurred, from approximately day 10 in the $35^{\circ} \mathrm{C}$ column. An overview of organic elimination data after 60 days, on the basis of coal and leached residue chemical analyses, was shown in Table2. Overall, the organic sulfur elimination data show very little grain size dependence, but the pyrite sulfur elimination data show very large grain size dependence.

The other factor contributing to the variability of the sulfur elimination was the sulfate ion concentration in the solution. The sulfate ion concentration in the range $100-140 \mathrm{gL}^{-1}$ were measured in the $1-3 \#$ columns leaching solutions. The $\mathrm{CaSO}_{4} \mathrm{~K}_{s p}$ values was $7.1 \times 10^{-5}$, hence $\mathrm{CaSO}_{4}$ has the highest concentration of sulphate ion in a saturated solution. However, when the concentration of sulfate ion concentration was too high, it would be precipitated in the form of calcium sulfate in the saturated solution, and then readhered to the surface of the coal, result in the desulfurization efficiency reduced. Since the sulfate ion was a main impurity contained on the surface of coal, controlling the sulfate ion concentration of the process solutions was important regarding coal microbial desulphurisation.

Table 3. Ash and Calorific value analyses of coal after desulphurisation

\begin{tabular}{llcccc}
\hline \multirow{2}{*}{ Analyses } & \multicolumn{4}{c}{ Duration(days) } \\
\cline { 3 - 6 } & & 15 & 30 & 45 & 60 \\
\hline \multirow{2}{*}{ 1\# } & Ash(wt\%) & 2.38 & 2.05 & 1.90 & 1.86 \\
& Calorific value(Kcal) & 6214 & 6348 & 6395 & 6410 \\
\hline \multirow{2}{*}{ 2\# } & Total sulfur & 2.51 & 2.24 & 2.15 & 2.02 \\
& Organic sulfur & 6185 & 6298 & 6322 & 6360 \\
\hline \multirow{2}{*}{ 3\# } & Total sulfur & 2.63 & 2.45 & 2.28 & 2.24 \\
& Organic sulfur & 6158 & 6215 & 6256 & 6275 \\
\hline \multirow{2}{*}{$4 \#$} & Total sulfur & 2.35 & 2.03 & 1.87 & 1.85 \\
& Organic sulfur & 6245 & 6386 & 6410 & 6425 \\
\hline
\end{tabular}

The contents of some minerals in the leached residues were compared with their content in the coal. The results showed that there was almost complete oxidation of pyrite but only moderate organic sulfur oxidation in inoculated tests, compared with the high sulfur coal. The subsequent precipitation of jarosite was also evident in the results for all columns, with ferric concentration and $\mathrm{pH}$ dependence. The presence of $\mathrm{Ca}^{2+}$ and $\mathrm{Mg}^{2+}$ in the solution was confirmed, corroborating the higher-than-expected acid consumptions.

The contents of ash decreased and calorific value increased markedly during leaching. The results show that the ash concentration of the smaller coal fraction and the coarser fraction can be decreased to1.86 and $2.24 \%$, respectively, from $2.83 \%$ in the 
original coal. Correspondingly, the calorific value of the finer coal fraction and the coarser fraction could be increased to 6410 and 6275 Kcal, respectively, from $5780 \mathrm{Kcal}$ in the original coal. The difference between the ashes of treated and original coals shows the existence of relevance between the rate of desulphurisation of the coal and degree of ash removed. This difference revealed a predominant remove of heavy metals, such as iron, calcium and manganese etc, caused by acidity of the (bio)leaching medium(Grossman et al., 1999). This was an advantage, when the problems associated with heavy metals happened in the ash after combustion of high sulfur coals, were considered.(Celin et al., 2005)

The mixed culture capable of oxidizing pyrite and removing sulfur from coals, addition of yeast extract to the medium did improve the degree of pyrite degradation and organic sulfur oxidation.

\subsection{Mechanism analysis}

Microbials have different mechanisms for using or eliminating sulphur element from high sulfur coal. The rate of sulfur eliminating from the coal was observed to be considerably similar with oxidation of pure pyrite for mesophilic bacteria. Consequently, during eliminate of inorganic sulfur of coal and oxidation of pure pyrite(reaction (1)) (Biao et al., 2014; Ruan et al., 2010 )showed similar values of the rate constant.

$$
\mathrm{FeS}_{2}(\mathrm{~s})+7 / 2 \mathrm{O}_{2}(a q)+\mathrm{H}_{2} \mathrm{O} \rightarrow \mathrm{Fe}^{2+}+2 \mathrm{SO}_{4}^{2-}+2 \mathrm{H}^{+}
$$

Eliminate of organic means a complete destroy of the whole molecule or a selective cleave of the C$S$ bond, we find advantage in this natural mesophile bacteria to eliminate the organic sulfur (DBT)from high sulfur coals. Further work was needed to determine the major culture composition and enzymatic system involving organic sulphur oxidation.

\section{CONCLUSIONS}

The result show that the mesophilic bacteria isolated from WuHai coal could remove $75 \%$ of total sulfur with coal particle size of $-6 \mathrm{~mm}$ in 60 days of oxidation time with column height 1.5 meters. The degree of sulfur elimination result indicated the competitive attack of the microorganisms on organic sulfur and inorganic sulfur. Also, it was observed that the ash content was reduced and the calorific value was increased due to gangue minerals dissolved in acidic mediums, this was an advantage of sulfur coals treated with acidophilus bacteria be considered. There was a generation of excessive high content of ferric iron and sulphate, which was mainly in the form of jarosite-like precipitates. They covered the coal surfaces and embedded sulfur in the precipitates became untouchable for microbial strains, leading to poor removing results, as was evident in our research(1-3\# columns). These problems did not occur while part discharge solutions neutralized with lime periodically in the present study(4\# columns).

\section{REFERENCES}

Acharya C, Kar RN, Sukla LB. 2001. Bacterial removal of sulphur from three different coals. Fuel 80(15):2207-2216.

Celin Acharya, L.B. Sukla, V.N. Misra.2005. Biological elimination of sulphur from high sulphur coal by Aspergillus-like fungi. Fuel 84(12-13):1597-1600.

G.Olsson,B.M. Pott, L.Larsson, O. Hoist , H.T. Karlsson.1994. Microbial desulfurization of coal by Thiobacillusferrooxidans and thermophilic archaea. Fuel Processing Technology 40: 277-282.

Grossman MJ,Lee MK, Prince RC,Garett KK, George GN,Pickering IJ. 1999. The Desulfurization Pathway in Rhodococcus.Appl Environ Microbiol 65(16):181-189.

M.van Afferden,D.Tappe,M.Beyer,H.G.Triiper.1993. Biochemical mechanisms for the desulfurization of coalrelevant organic sulfur compounds. Fuel 72(12):1635-1643.

RUAN RM, ZHOU E, LIU XY, WU B, ZHOU GY, WEN JK.2010. Comparison on the leaching kinetics of chalcocite and pyrite with or without bacteria. Rare Metals 29(6):552555.

Wu Biao, Wen Jian-Kang, Chen Bo-Wei, Yao Guo-Cheng, Wang Dian-Zuo. 2014.Control of redox potential by oxygen limitation in selective bioleaching of chalcocite and pyrite.Rare Metals 33(5):622.

Xiangsheng, Dejun, Chunyan.2012.Isolation and identification of biosurfactant producing and crude oil degrading Pseudomonas aeruginosa strains. Chemical Engineering Journal 209:138-146. 